\title{
Selection and use recommendation in hybrids of ornamental pineapple ${ }^{1}$
}

\author{
Seleção e recomendação de uso de híbridos ornamentais de abacaxi
}

\author{
Everton Hilo de Souza ${ }^{2 *}$, Maria Angélica Pereira de Carvalho Costa ${ }^{3}$, Janay Almeida Santos-Serejo ${ }^{4}$ e Fernanda \\ Vidigal Duarte Souza ${ }^{4}$
}

\begin{abstract}
The use of pineapples as ornamental plants has increased in the last years due to their beauty and originality, demanding the generation of new varieties. The objective of the present work was to study the genetic variability and type of use of hybrids as ornamental pineapples, besides evaluating the resistance of these hybrids to Fusarium wilt. Six progenies, FRF-22 X FRF-1387, FRF-1392 X FRF-32, Curauá Roxo X Ananás Tricolor, G-44 X FRF-1387, FRF-1392 X FRF-224 and FRF-1387 X FRF-224, were evaluated by eleven morphological descriptors, and five categories of use were taken into account: landscaping plants, cut flower, potted plants, minifruits and foliage. High variability within and between progenies was detected, which allowed the selection of 16 hybrids as cut flowers, 17 as landscaping plants, four as minifruits, two as potted plants and just three as foliage. Fourteen of them were recorded for more than one type of use. For resistance to the Fusarium, out of the 31 hybrids evaluated, 11 presented resistance, 17 were moderately resistant and three were susceptible.
\end{abstract}

Key words: Ananas sp.. Hybridization. Morphological descriptors. Ornamental fruit crops. Phytosanitary

\begin{abstract}
RESUMO - O uso do abacaxi como planta ornamental vem se intensificando nos últimos anos, por sua beleza e originalidade e é crescente a demanda por novas variedades. O objetivo desse trabalho foi estudar a variabilidade genética em progênies de abacaxi ornamental, identificando as formas de uso e a resistência à fusariose dos híbridos selecionados. Foram aplicados onze descritores morfológicos em seis progênies: FRF-22 X FRF-1387, FRF-1392 X FRF-32, Curauá Roxo X Ananás Tricolor, G-44 X FRF-1387, FRF-1392 X FRF-224 e FRF-1387 X FRF-224, sendo os híbridos enquadrados nas categorias de paisagismo, corte, vaso, minifrutos e folhagens e cerca-viva. Em paralelo foi estudado a resistência a fusariose dos híbridos selecionados. Foi verificada grande variabilidade entre e dentro das progênies, permitindo selecionar 16 híbridos para flor de corte, 17 para paisagismo, quatro para minifrutos, dois para vasos e apenas três para folhagem, sendo 14 com mais de uma forma de uso. Dos 31 híbridos avaliados para a fusariose, 11 apresentaram resistência, 17 moderadamente resistente e três suscetíveis.
\end{abstract}

Palavras-chave: Ananas sp.. Hibridação. Descritores morfológicos. Fruticultura ornamental. Fitossanidade.

\footnotetext{
* Autor para correspondência

${ }^{1}$ Recebido para publicação em 20/11/2012; aprovado em 08/01/2014

Pesquisa financiada pelo Banco do Nordeste S/A e Coordenação de Aperfeiçoamento de Pessoal de Nível Superior (CAPES)

${ }^{2}$ Centro de Energia Nuclear na Agricultura, Universidade de São Paulo, Caixa Postal 96, Piracicaba-SP, Brasil, hilosouza@gmail.com

${ }^{3}$ Centro de Ciências Agrárias, Ambientais e Biológicas, Universidade Federal do Recôncavo da Bahia, Cruz das Almas-BA, Brasil, mapcosta@ ufrb.edu.br

${ }^{4}$ Embrapa Mandioca e Fruticultura, Cruz das Almas-BA, Brasil, janay@embrapa.br, fernanda.souza@embrapa.br
} 


\section{INTRODUCTION}

Pineapple [Ananas comosus (L) Merr.] presents wide genetic diversity, mainly in Brazil, one of the centers of origin and dispersion of these Bromeliaceae (SOUZA et al., 2007; 2012). This genetic variability, however, has been little explored yet, in spite of the potential of these plants to generate several products, mainly fibers for the manufacture of rustic material, such as ropes and fabric; the use in the automotive industry as a source of nanocellulose plastic, more resistant ho heat, gasoline and water and he envisions using it for dashboards, bumpers and body panels (LEÃO et al., 2009; MOHANTY et al., 2000; ZAH et al., 2007), manufacture of paper (MARQUES; GUTIÉRREZ; DEL RIO, 2007), proteolytic enzymes (MAURER, 2001) and secondary metabolites with antioxidant and biological activities of great value for the pharmaceutical, cosmetic and food industry (HARVEY, 2000; MANETTI; DELAPORTE; LAVERDE JUNIOR, 2009), besides its great ornamental potential (CHAN, 2006; COPPENS D'EECKENBRUGGE; DUVAL, 2009; DUVAL et al., 2001; SANEWSKI, 2009; SOUZA et al., 2007; 2009).

Furthermore, similarly to other Bromeliaceae, pineapples in their wild or non-cultivated forms have extraordinary characteristics for ornamental use. Wild genotypes present diversity of shapes and colors that stand out for their beauty, originality and the durability of their fruits and leaves (SOUZA et al., 2007; 2012).

On the other hand, it must be highlighted that floriculture is an activity that involves the production of cut flowers, pot plants and gardening and generates employment and income (VENCATO, 2006). This activity demands the constant generation of novelties and the development and use of tropical plants.

The offer of new varieties, however, depends on the identification of new materials in the genetic resource that exists inside the genus, or the generation of hybrids in genetic breeding programs.

The present work was carried out considering mainly the wild botanic varieties ananassoides, bracteatus and erectifolius, focusing not only on the search for genotypes for use as cut flower, but also on pot plants and landscaping. Two new categories of use were inserted in this selection, ornamental minifruits and cut foliage. Minifruits are a novelty that has delighted consumers, creating a peculiar and special market niche (SOUZA et al., 2007; 2009; 2012). There is a strong demand in the domestic and external markets for foliage nowadays, mainly in Europe. It has been widely used to complement floral arrangements, giving a special aspect to them and allowing diversification in their composition. Therefore, many tropical species are potential candidates for this market, due to the exuberance and originality of their leaves, including pineapples.

Another aspect to be considered in this work is the resistance of the hybrids achieved to the main pests that affect commercial pineapple crops. Fusarium is the main pest for the genus Ananas. Its etiological agent is the fungus Fusarium subglutinans (Wollenweber and Reinking) Nelson, Toussoun and Marasas f. sp. ananas Ventura, Zambolim and Gilbertson. The cultivation of resistant varieties is the most efficient and economical control measure for this culture (MATOS; CABRAL, 2006). Therefore, the conduction of assays to identify resistant or susceptible hybrids in the progenies achieved is essential for the conclusion of the work.

Thus, the objectives of this work were to characterize progenies of ornamental pineapple by clustering the hybrids into categories of use and evaluating the resistance to Fusarium in the hybrids selected.

\section{MATERIALS AND METHODS}

The work was conducted at the Pineapple Germplasm Bank and field experimental area at Embrapa Cassava and Fruit, located at $12^{\circ} 40^{\prime} \mathrm{S}$ and $39^{\circ} 06^{\prime}$ W, in the municipality of Cruz das Almas, in the Recôncavo da Bahia, Brazil.

According to the Köppen classification (KÖPPEN, 1936) the climate in the municipality of Cruz das Almas is a transition between the Am and Aw zones, with average annual rainfall of $1143 \mathrm{~mm}$, average temperature of $24.28^{\circ} \mathrm{C}$ and relative humidity of $60.47 \%$. The soil of the experimental area is a typical dystrophic yellow latosol, moderate A, with sandy clay loam texture, kaolinitic hypoferric, subperennial and semideciduous forest transition phase, with 0 to $3 \%$ slope.

The progenies evaluated resulted from the following crossings: A. comosus var. bracteatus (FRF-22) $\mathrm{X}$ A. comosus var. erectifolius (FRF-1387), A. comosus var. erectifolius (FRF-1392) X A. comosus var. bracteatus (FRF-32), A. comosus var. erectifolius (Curauá Roxo) X A. comosus var. bracteatus (Ananás Tricolor), A. comosus var. ananassoides (G-44) X A. comosus var. erectifolius (FRF-1387), A. comosus var. erectifolius (FRF-1392) $\mathrm{X}$ A. comosus var. ananassoides (FRF-224) and $A$. comosus var. erectifolius (FRF-1387) X A. comosus var. ananassoides (FRF-224). The plants with spines in their leaves were discarded from this evaluation.

Eleven morphological descriptors developed by the "International Board for Plant Genetic Resources" 
(IBPGR, 1991) were applied and used for pineapple genetic resources.

The following characteristics were evaluated: plant habit (PHA), plant height (PHE), canopy diameter (CAN); leaf length 'D' (LLE), leaf width 'D' (LDI); peduncle length after closure of the last flower (LPE), peduncle diameter after closure of the last flower (DPE), syncarp length after closure of the last flower (SYL), syncarp diameter after closure of the last flower (SYD), crown length after closure of the last flower (LCR) and crown/syncarp ratio, achieved by the crown length $\mathrm{x}$ syncarp length $(\mathrm{C} / \mathrm{S})$ ratio.

After morphological characterization, the hybrids were selected and grouped into categories of use: potted plants, cut flower, minifruits, landscape plants and foliage as described by Souza et al. (2012).

The following descriptive statistics were calculated: average, minimum value, maximum value, standard deviation and variation coefficient, considering all the hybrids evaluated. For data analysis, we used the SAS statistical software system (SAS, 2004). For the describer related to plant habit, it was calculated the percentage frequency in each crossing, since this variable is categorical.

Following the selection of the hybrids, assays for resistance to Fusarium were carried out. The isolate Fusarium subglutinans f. sp. ananas, number CAL001/2010, was cultivated in BDA medium (potato, $200 \mathrm{~g}$; dextrose, $10 \mathrm{~g}$; agar, $18 \mathrm{~g} ; 1.000 \mathrm{~mL}$ ). The inoculum was prepared after seven days of incubation under laboratory conditions, by adding sterile distilled water to the culture plate, removing the conidia through the use of a fine brush and filtering the suspension in two layers of gauze. The conidial concentration was determined by counting in a Neubauer hemacytometer, and was adjusted for $1 \times 10^{-5}$ conidia $\mathrm{ml}^{-1}$ (MATOS; CABRAL, 2006).

The methodology developed by Matos (1978), used to inoculate seedlings, consists of performing equidistant injuries at the base of the seedlings, followed by immersion in a conidial suspension for three minutes and planting in cement beds, where they remain under field conditions throughout the experiment. Soil humidity was maintained in the beds through regular watering, when necessary.

After 90 days, the seedlings were pulled out from the soil and the internal symptoms at the base of the inoculated seedlings were assessed by the measurement of the size of the lesion in relation to the inoculation site. The following rating scale from 0 (zero) to 5 (five) was also adopted: without symptoms (0); early rot (1); mild rot (2); average rot (3); severe rot (4) and seedling base completely rotten, causing the death of the plant (5) (SOUZA et al., 2011). The experiment was arranged in a completely randomized design, with six replications and two controls, namely, the susceptible cultivar Pérola and the resistant hybrid PEXSC73. To corroborate the efficiency of the inoculation, plants from the cultivar Pérola were inoculated with sterile distilled water. For data analysis, we used the SAS statistical software system (SAS, 2004). They were grouped and ranked as: 0 resistant; 0.1 to 2.0 moderately resistant; and 2.1 to 5.0 susceptible.

\section{RESULTS AND DISCUSSION}

Table 1 presents a descriptive analysis of the characteristics evaluated and gives an overview of the behavior of each variable, within each crossing, considering all crossings. It was observed great variability within the crossings and between crossings (Table 1 and Figure 1). The greatest variation was recorded in the character length of the crown and crown/syncarp ratio, which can be observed in the variation coefficient for these characteristics. On the other hand, the crossing G-44 X FRF-1387 provided the greatest contribution for this variation, mainly due to the occurrence of fruits free from crown, and fruits with crown approximately $23.7 \mathrm{~cm}$ long.

Plant height is a defining characteristic in the selection of ornamental pineapples, due to its significant effect on the categories of use intended for the hybrid, mainly when pot plants are desired, since they must be preferably short, with small and compact canopies.

Large plants are indicated for landscaping, mainly in large areas, such as parks and gardens. The crossing Curauá Roxo X Ananás Tricolor presented plants with higher average height $(102.6 \mathrm{~cm})$, canopy diameter of $119 \mathrm{~cm}, 95.4 \mathrm{~cm}$ long and leaf $4.9 \mathrm{~cm}$ wide.

This was the best crossing for landscaping, not only due to the size of the plants, but also for the number of genotypes with variegation on the leaves. Some hybrids achieved from this crossing could also be used as cut leaf, since their length and width are appropriate for this purpose.

Foliages stand out as products with high market strategic potential and increasing acceptance in the international market. Pineapple leaves (Figure 1a) are an interesting alternative for this market, due to their beauty and post-harvest long life. Preliminary assays in floral sponges lasted about 30 days, which is much 
Table 1 - Average, minimum value, maximum value, $F$, standard deviation and variation coefficient $(\mathrm{CV})$ for ten descriptors of ornamental pineapple plants

\begin{tabular}{lcccccccccc}
\hline & \multicolumn{10}{c}{ Descriptor } \\
\cline { 2 - 11 } & PHE & CAN & LLE & LWI & LPE & DPE & SYL & SYD & LCR & C/S \\
\hline Average & 75.3 & 101.8 & 69.5 & 3.8 & 32.8 & 1.3 & 6.8 & 4.4 & 5.9 & 0.9 \\
Minimum & 34.5 & 45.0 & 26.0 & 1.5 & 11.0 & 0.6 & 2.5 & 2.0 & 0.0 & 0.0 \\
Maximum & 152.0 & 195.0 & 145.0 & 7.0 & 63.0 & 2.3 & 23.7 & 11.0 & 21.5 & 3.1 \\
CV (\%) & 20.6 & 20.7 & 19.1 & 21.0 & 26.3 & 27.0 & 30.3 & 21.2 & 35.4 & 38.8 \\
F & $8.3^{* *}$ & $9.5^{* *}$ & $5.5^{* *}$ & $11.2^{* *}$ & $11.0^{* *}$ & $20.5^{* *}$ & $12.2^{* *}$ & $32.2^{* *}$ & $8.0^{* *}$ & $12.6^{* * *}$ \\
SD & 14.9 & 18.1 & 13.4 & 0.9 & 9.7 & 0.2 & 1.9 & 0.9 & 2.7 & 0.4 \\
\hline
\end{tabular}

A. comosus var. bracteatus (FRF-22) x A. comosus var. erectifolius (FRF-1387)

\begin{tabular}{ccccccccccc} 
Average & 77.6 & 92.9 & 69.1 & 3.4 & 35.9 & 1.3 & 6.1 & 4.9 & 6.6 & 1.1 \\
\hline \multicolumn{7}{c}{ A. comosus var. erectifolius } & (FRF-1392) x A. comosus var. bracteatus (FRF-32) \\
Average & 64.0 & 102.5 & 63.9 & 3.8 & 31.3 & 1.2 & 5.6 & 4.1 & 4.9 & 0.9 \\
\hline
\end{tabular}

A. comosus var. erectifolius (Curauá Roxo) x A. comosus var. bracteatus (Ananás Tricolor)

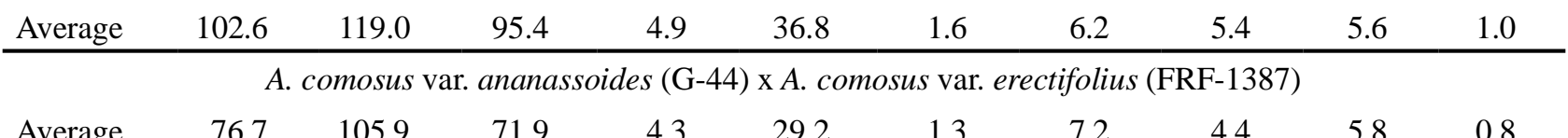

\begin{tabular}{lllllllllll} 
Average & 76.7 & 105.9 & 71.9 & 4.3 & 29.2 & 1.3 & 7.2 & 4.4 & 5.8 & 0.8 \\
\hline \multicolumn{7}{c}{ A. comosus var. erectifolius } & (FRF-1392) x A. comosus var. ananassoides (FRF-224) \\
Average & 52.0 & 77.8 & 56.2 & 2.4 & 41.2 & 1.1 & 6.4 & 4.1 & 5.5 & 0.9 \\
\hline
\end{tabular}

A. comosus var. erectifolius (FRF-1387) x A. comosus var. ananassoides (FRF-224)

$\begin{array}{lllllllllll}\text { Average } & 67.2 & 96.3 & 60.1 & 2.5 & 44.1 & 0.9 & 5.9 & 3.8 & 4.9 & 0.8\end{array}$

PHE = plant height $(\mathrm{cm})$; CAN = canopy diameter $(\mathrm{cm}) ;$ LLE = leaf length ' $\mathrm{D}$ ' $(\mathrm{cm}) ;$ LWI = leaf width 'D' $(\mathrm{cm}) ;$ LPE = peduncle length after closure of the last flower $(\mathrm{cm})$; DPE peduncle diameter after closure of the last flower $(\mathrm{cm}) ; \mathrm{SYL}=$ syncarp length after closure of the last flower $(\mathrm{cm})$; $\mathrm{SYD}=$ syncarp diameter after closure of the last flower $(\mathrm{cm}) ; \mathrm{LCR}=$ crown length after closure of the last flower $(\mathrm{cm}), \mathrm{C} / \mathrm{S}=\mathrm{crown} / \mathrm{syncarp}(\mathrm{cm})$ relation. ** significant at $1 \%$ by $F$ test

longer than most foliages used in floral arrangements (SOUZA et al., 2009).

The hybrids of the crossings FRF-1392 X FRF224 and FRF-1387 X FRF-224 presented the smallest plants, with the lowest values for height, canopy diameter and length and width of the leaves. These characteristics were probably inherited from the parent FRF-224, which presents reduced size, decumbent habit, short and thin leaves, long peduncle and small fruits.

The hybrids from the crossing FRF1392 X FRF224 presented the lowest plant height $(52 \mathrm{~cm})$, lowest canopy diameter $(77.8 \mathrm{~cm})$ and shortest leaf length $(56.2 \mathrm{~cm})$ for the selection of potted plants. On the other hand, their peduncles were long $(41.2 \mathrm{~cm})$, which is an undesirable trait for this category (Table 1).
Another important characteristic is the length of the peduncle (stem), which defines the selection of genotypes for cut flower. The export market requires stems longer than $40 \mathrm{~cm}$, without deformations and good resistance to dropping (SOUZA et al., 2012).

For the domestic market, in the case of ornamental pineapples, undulation is not (Figure 1b) a limiting factor, since preliminary assays (data not shown) revealed that national florists prefer undulated peduncles because they give movement to floral arrangements.

Peduncles with minimum length of $11 \mathrm{~cm}$ and maximum length of $63 \mathrm{~cm}$ were achieved from different crossings, as shown in Table 1 . The hybrids from the crossing FRF-1387 X FRF-224 presented the longest peduncles, with $85 \%$ of the hybrids taller than $40 \mathrm{~cm}$. 
Figure 1 - Variability achieved from different crossings: a variability of leaf; $\mathbf{b}$ variability of shape, thickness and color of peduncle; $\mathbf{c}$ variability of fruits, revealing the crown/ syncarp ratio; $\mathbf{d}$ variability of color and shape of fruits; $\mathbf{e}$ variability of shape and color in crowns. f-q hybrids selected from different crossings: f FRF-22 X FRF-1387/ PL02; g FRF-22 X FRF-1387/ PL12; h FRF-1392 X FRF-32/ PL01; i FRF-1392 X FRF-32/ PL06; j FRF-1392 X FRF-32/ PL07; k Curauá Roxo X Ananás Tricolor/ PL05; I Curauá Roxo X Ananás Tricolor/ PL06; m Curauá Roxo X Ananás Tricolor/ PL08; n G-44 X FRF-1387/ PL02; o G-44 X FRF-1387/ PL04; p FRF-1392 X FRF-224/ PL03; q FRF-1387 X FRF-224/ PL01. Bar 1.00 cm

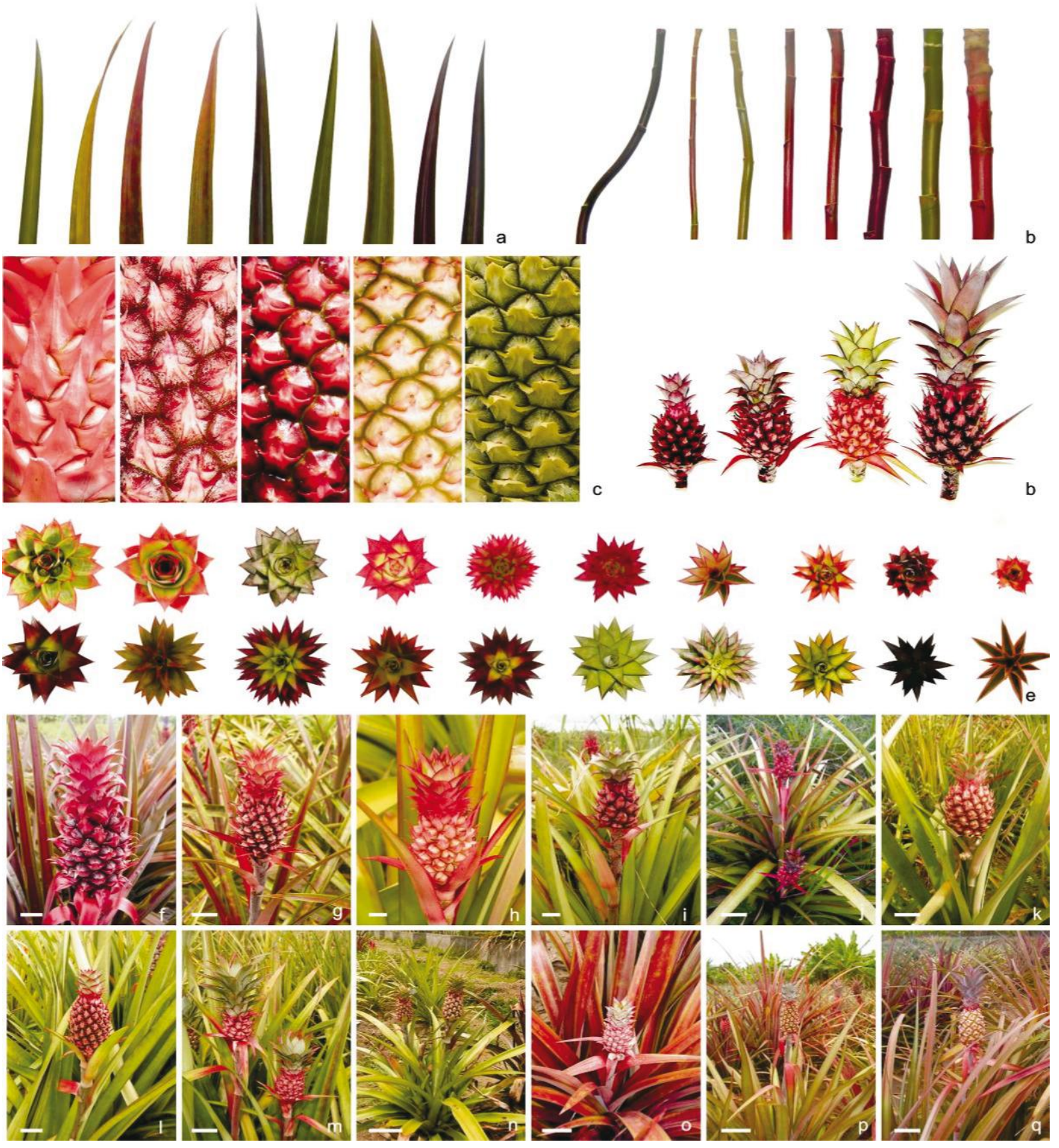

The average observed for peduncle diameter was $1.3 \mathrm{~cm}$, varying from $0.6 \mathrm{~cm}$ to $2.3 \mathrm{~cm}$ (Table 1 ). The search for thin peduncles with good resistance to fruit break is mainly due to decreased weight, which facilitates handling and reduces the costs of transportation, mainly for export. 
Concerning the length and diameter of fruits, no differences were observed among the crossings. In general, the crossings containing A. comosus var. ananassoides presented smaller fruits. On the other hand, the crossings that involved parents with A. comosus var. bracteatus produced larger fruits, according to the characteristics of their parents. The color of the fruits ranged from light green and intense red to dark purple (Figure 1d).

Table 2 presents the percentage results of the different crossings carried out for the growth habit of the plants achieved. It is possible to observe the prevalence of normal growth habit, even when the hybrids result from crossings between plants with erect and decumbent habit, which demonstrates that this trait is dominant. However, further studies on this subject are necessary to understand the segregations observed. This character is possibly controlled by several independent genes with additive action.

The final selection within each crossing was carried out according to the beauty of the set, considering the colors, the presence of variegation and absence of spines.

As for resistance to the Fusarium, out of the 31 hybrids evaluated, 11 presented resistance, 17 were moderately resistant and three were susceptible. It was observed that all the plants of the cultivar Pérola, used as susceptible control, died, while the hybrid PEXSC73, used as resistant control, did not present any symptoms, corroborating the adequacy of the procedures used for this evaluation.

The crossing FRF-22 X FRF-1387 generated 1830 seeds. Out of these, 200 well developed plants free from spines were selected for assessment.

After grouping according to use, six hybrids were selected, three for cut flower (PL02, PL07 and PL12), and three for landscaping (PL01, PL03 and PL14). All hybrids showed normal growth habit. Two of them were resistant to Fusarium (PL03 and PL07), three were moderately resistant (PL02, PL12 and PL14) and one was susceptible (PL01). The hybrids PL02 (Figure 1f) and PL12 (Figure $1 \mathrm{~g}$ ) were moderately resistant to Fusarium and presented the highest ornamental potential. Both were selected for cut flower and landscaping, because of their long peduncle (longer than $41 \mathrm{~cm}$ ), intense red fruit, average syncarp length of $7.5 \mathrm{~cm}$, and crown of $6.5 \mathrm{~cm}$.

The crossing FRF-1392 X FRF-32 provided 920 seeds, and 158 plants from these seeds were carried to the field. After grouping per category of use, six hybrids were selected (PL01, PL03, PL05, PL06, PL07 and PL08). All hybrids showed normal growth habit and moderately resistant to Fusarium. Two of them are recommended for cut flower (PL03 and PL05), two for pot plant (PL07 and PL08) and two for minifruits (PL01 and PL06). PL01 presented the highest ornamental potential, with green color, short leaves $(66.1 \mathrm{~cm})$, short peduncle $(26 \mathrm{~cm})$, small and ovoid fruit, nearly $4.5 \mathrm{~cm}$ long and $3.5 \mathrm{~cm}$ in diameter, intense pink color, crown with green and pink spots, ideal to be used as minifruits (Figure 1h). The hybrid PL 06 has short $(20 \mathrm{~cm})$ and thin $(1 \mathrm{~cm})$ peduncle, reddish, trapezoidal syncarp with wide base, $4 \mathrm{~cm}$ long and $3.4 \mathrm{~cm}$ in diameter, green crown, contrasting with the syncarp, with great potential for minifruits (Figure 1). Another potential accession is PL07, indicated to be used as pot plant. The hybrid has green and short $(45 \mathrm{~cm})$ leaves, with distribution of anthocyanin in the edges, reduced height $(34.5 \mathrm{~cm})$, short peduncle $(18 \mathrm{~cm})$, syncarp and small crown. Another characteristic observed is the presence of clumps, which allow the formation of massifs for landscaping (Figure 1j).

The crossing between Curauá Roxo and Ananás Tricolor generated 300 seeds. Sixty-three plants from these seeds were carried to the field. Five hybrids with great potential for landscaping were selected (PL02, PL05, PL06, PL07 and PL08). Two of them were also selected for both cut flower and foliage (PL05 and PL06) and only

Table 2 - Percentage frequency related to the growth habit of the genotypes from the different crossings performed

\begin{tabular}{lcccccc}
\hline & \multicolumn{7}{c}{ Crossings } \\
\cline { 2 - 7 } & FRF-22 & FRF-1392 & Curauá Roxo & G-44 & FRF-1392 & FRF-1387 \\
Growth habit & (normal) & (erect) & (erect) & (normal) & (erect) & (erect) \\
& $\mathrm{X}$ & $\mathrm{X}$ & $\mathrm{X}$ & $\mathrm{X}$ & $\mathrm{X}$ & $\mathrm{X}$ \\
& FRF-1387 & FRF-32 & Ananás Tricolor & FRF-1387 & FRF-224 & FRF-224 \\
& (erect) & (normal) & (decumb.) & (erect) & (decumb.) & (decumb.) \\
\hline Normal & $87 \%$ & $89 \%$ & $100 \%$ & $71 \%$ & $100 \%$ & $100 \%$ \\
Erect & $12 \%$ & $4 \%$ & - & $25 \%$ & - & - \\
Decumbent & $1 \%$ & $7 \%$ & - & $4 \%$ & - & - \\
\hline
\end{tabular}


one for foliage (PL08). The selection of a hybrid with recommendation for more than one category is interesting, since this plasticity of use gives more value to the product. Therefore, the hybrids PL05 (Figure 1k) and PL06 (Figure 11) were selected. All hybrids showed normal growth habit, out of these, five hybrids moderately resistant to Fusarium (PL05, PL06, PL07 and PL08) and one is susceptible (PL02). Both presented green leaves, more than $90 \mathrm{~cm}$ long and $5 \mathrm{~cm}$ wide, the syncarp was $7.2 \mathrm{~cm}$ long, $6.6 \mathrm{~cm}$ in diameter. The hybrid PL05 presented a very peculiar globose shape, while the hybrid PL06 was ovoid. The peduncles of both hybrids were longer than $47 \mathrm{~cm}$, with diameter shorter than $1.6 \mathrm{~cm}$, which makes them appropriate for the cut flower category. The hybrid PL08 presented greenish crown with pink edges, in the shape of flower, due to the curve of the leaves, differing from the others (Figure $1 \mathrm{~m}$ ).

The shape and color of the crowns observed in this crossing were peculiar and highly exuberant, which makes these hybrids extremely beautiful (Figure 1e).

Out of the 720 seeds produced in the G-44 X FRF-1387 crossing, 285 were assessed in the field. It resulted in the selection and recommendation of three hybrids with potential for landscaping (PL03, PL04 and PL07), one for minifruit (PL02), one for cut flower (PL06) and one for cut flower and foliage (PL05). Out of these, three are resistant to Fusarium (PL02, PL03 and PL07), two are moderately resistant (PL04 and PL06) and one is susceptible (PL05). All hybrids presented normal growth habit with the exception to PL05 that has erect growth habit. The hybrids PL02 and PL04 presented the highest ornamental potential. The hybrid PL02 is resistant to Fusarium, has short $(66 \mathrm{~cm})$ green leaves, peduncle nearly $20 \mathrm{~cm}$ long and small $(5 \mathrm{~cm})$ ovoid fruits. Such characteristics are essential for minifruits (Figure 1n). The hybrid PL04 is moderately resistant, has reddish leaves, approximately $75 \mathrm{~cm}$ long, peduncle of about $20 \mathrm{~cm}$ and reddish ovoid fruit with small crown (Figure 1o).

The two last crossings generated 1730 seeds, out of which 630 were from the crossing FRF-1392 X FRF224 and 1100 were from the crossing FRF-1387 X FRF224 and all showed normal growth habit. Assessments were carried out in 30 and 71 plants, respectively. Eighty percent of the 101 plants evaluated presented peduncle longer than $40 \mathrm{~cm}$, and $100 \%$ diameter less than $1.30 \mathrm{~cm}$, a trait probably inherited from the parent FRF-224. Another important characteristic in these crossings is resistance to Fusarium, since the six hybrids are resistant (FRF-1392 X FRF-224 - PL01, PL03, PL04 and FRF-1387 X FRF-224 - PL01, PL03, PL04) and two, moderately resistant (FRF-1387 X FRF-224 - PL02, PL06).
The hybrids that showed potential for cut flower were PL03, from the crossing FRF-1392 X FRF-224 (Figure 1p) and PL01, from the crossing FRF-1387 X FRF-224 (Figure 1q) presented the highest potential for cut flower. Their plants have green leaves with thin reddish margins, with approximately $2.3 \mathrm{~cm}$, the peduncle is $43 \mathrm{~cm}$ long, $1.1 \mathrm{~cm}$ in diameter and ovoid light green syncarp, $6 \mathrm{~cm}$ long.

Finally, the variability observed in the progenies obtained allowed the identification of several genotypes that can be recommended for different purposes, giving to ornamental pineapple a plasticity that is very rare in species used in floriculture.

The results achieved in this work will allow the launching of new varieties of ornamental pineapple in the next years, both for the domestic market and export, and will give support to new crossings, mainly targeting the achievement of smaller pot plants.

Nowadays, assays for agronomic validation have been conducted, whose main objective is to evaluate the behavior of hybrids achieved under the existent cultivation system for ornamental pineapple. Simultaneously, studies have been carried out aiming at the post-harvest of the hybrids achieved, mainly the genotypes selected for cut flower and minifruits.

\section{CONCLUSION}

High variability within and between progenies was detected, which allowed the selection of 16 hybrids as cut flowers, 17 as landscaping plants, four as minifruits, two as potted plants and just three as foliage. Fourteen of them were recorded for more than one type of use. For resistance to the Fusarium, out of the 31 hybrids evaluated, 11 presented resistance, 17 were moderately resistant and three were susceptible.

\section{ACKNOWLEDGMENTS}

To the Banco do Nordeste S/A, for the financial support to the project, Coordenação de Aperfeiçoamento de Pessoal de Nível Superior (CAPES) for the scholarships granted.

\section{REFERENCES}

CHAN, Y. K. Hybridisation and selection in pineapple improvement. The experience in Malaysia. Acta Horticulturae, v. 702, p. 87-92, 2006. 
COPPENS D'EECKENBRUGGe, G. C.; DUVAL, M. F. The domestications of pineapple: context and hypotheses. Pineapple News, v. 16, p. 15-26, 2009.

DUVAL, M. F. et al. Ornamental pineapple: perspective from clonal and hybrid breeding. Pineapple News, v. 8, p. 13-14, 2001.

HARVEY, A. Strategies for discovering drugs from previously unexplored natural products. Drug Discovery Today, v. 5, n. 7, p. 294-300, 2000.

IBPGR - International Board for Plant Genetic Resources. Descriptors for pineapple. Rome. 1991. 74p.

KÖPPEN, W. Das seographische system der climate. In: KÖPPEN W.; GEIGER, R. (ed.) Handbuch der klimatologie, v. 1, Part C. Gebrfider Borntraeger, Berlin, Germany, 1936.

LEÃO, A. L. et al. Production of curaua fibers for industrial applications: characterization and micropropagation. Acta Horticulturae, v. 822, p. 227-238, 2009.

MANETTI, L. M.; DELAPORTE, R. H.; LAVERDE JURIOR, A. Metabólitos secundários da família Bromeliaceae. Química Nova, v. 32, n. 7, p. 1885-1897, 2009.

MARQUES, G.; GUTIÉRREZ, A.; DEL RIO, J. C. Chemical Characterization of Lignin and Lipophilic Fractions from Leaf Fibers of Curaua (Ananas erectifolius). Journal of Agricultural and Food Chemistry, v. 55, n. 4, p. 1327-1336, 2007.

MATOS, A. P. Métodos de inoculação com Fusarium moniliforme Sheld. var. subglutinans WR \& RG em abacaxizeiro 'Pérola'. Revista Brasileira de Fruticultura, v. 1, n.1, p. 37-42, 1978.

MATOS, A. P.; CABRAL, J. R. S. Evaluation of Pineapple Genotypes for Resistance to Fusarium subglutinans. Acta Horticulturae, v. 702, p. 73-77, 2006.
MAURER, H. R. Bromelain: biochemistry, pharmacology and medical use. CMLS Cellular and Molecular Life Sciences, v. 58, p. 1234-1245, 2001.

MOHANTY, A. et al. Chemical modification of pineapple leaf fiber: Graft copolymerization of acrylonitrile onto defatted pineapple leaf fibers. Journal of Applied Polimers Science, v. 77, n. 14, p. 3035-3043, 2000.

SANEWSKI, G. M. Breeding Ananas for the cut-flower and garden markets. Acta Horticulturae, v. 822, p. 71-78, 2009.

SAS Institute Inc SAS/STAT User's Guide. Version 9.1.3, 2004.

SOUZA, E. H. et al. Evaluation of ornamental pineapple hybrids for resistance to Fusarium subglutinans f. sp. ananas. Acta Horticulturae, v. 902, p. 381-386, 2011.

SOUZA, E. H. et al. Genetic variation of the Ananas genus with ornamental potential. Genetic Resources and Crop Evolution, v. 59, n. 7, p. 1357-1376, 2012.

SOUZA, F. V. D. et al. Caracterização morfológica de abacaxizeiros ornamentais. Magistra, v. 19, n. 4, p.319-325, 2007.

SOUZA F. V. D. et al. Evaluation of F1 hybrids between Ananas comosus var. ananassoides and Ananas comosus var. erectifolius. Acta Horticulturae, v. 822, p. 79-84, 2009.

VENCATO, A. Anuário Brasileiro das Flores 2006. Gazeta Santa Cruz, Santa Cruz do Sul, 2006. 112p.

ZAH, R. et al. Curauá fibers in the automobile industry - a sustainability assessment. Journal of Cleaner Production, v. 1, n. 11-12, p.1032-1040, 2007. 